DOI: 10.46340/eujem.2020.6.4.9

Oksana Nikishyna, ScD in Economics

ORCID ID: https://orcid.org/0000-0002-7172-3551

Tetiana Lozova

ORCID ID: https://orcid.org/0000-0002-4896-1930

Mykola Tarakanov, PhD in Economics

ORCID ID: https://orcid.org/0000-0002-3827-237

Institute of Market Problems and Economic \& Ecological Research

of National Academy of Sciences of Ukraine

\title{
FORMATION AND REGULATION \\ OF EFFECTIVE LOGISTICS CHAINS \\ ON THE FRUIT AND BERRY MARKET \\ IN UKRAINE
}

\author{
Оксана Нікішина, д. е. н. \\ Тетяна Лозова \\ Микола Тараканов, к. е. н. \\ Інститут проблем ринку та економіко-економічних досліджень НАН України \\ ФОРМУВАННЯ Й РЕГУЛЮВАННЯ \\ ЕФЕКТИВНИХ ЛОГІСТИЧНИХ ЛАНЦЮГІВ \\ ПЛОДОВО-ЯГІДНОГО РИНКУ УКРАЇНИ
}

The logistic tendencies of development of the Ukrainian market of fruit and berry production, logistic alienation of small commodity producers from a link of distribution and realization of production are defined. The inefficiency of existing logistics chains of the market is proved. The necessity of forming cooperative logistics chains, which include multifunctional fruit and berry cooperatives, logistic center and branded retail stores, is substantiated. The directions and measures of the state support of development of effective chains of cooperative type are defined. The role of effective cooperative chains in the implementation of a balanced policy of import substitution in the food markets of Ukraine is determined.

Keywords: logistics chain, link, market, fruit and berry products, individual farms, value added, import substitution.

Постановка проблеми. В умовах економічної невизначеності першочерговим завданням держави постає забезпечення ефективного функціонування стратегічних товарних ринків для нарощування доданої вартості та забезпечення національної економічної безпеки. Український ринок плодово-ягідної продукції (далі - ПЯП) має потужний природно-ресурсний, виробничий, трудовий та інноваційний потенціал для відтворювального розвитку, який залишається нереалізованим. Характерною особливістю даного ринку $\epsilon$ логістична природа його відтворювального розвитку, тобто невирішені логістичні проблеми, системні логістичні «розриви», що поглиблюються та продукують низку структурних і цінових дисбалансів, чинять глибинний деструктивний вплив на розвиток всього ринку. Ланцюговий підхід до дослідження ринку ПЯП дозволяє ідентифікувати базові логістичні «розриви» та оцінити пропорції перерозподілу доданої вартості між ланками ринкового ланцюга. Практика свідчить, що існуючі логістичні ланцюги ринку ПЯП є неефективними з позиції реалізації економічних інтересів дрібних виробників, держави та споживачів. Відтак, постає необхідність у перебудові діючих або формуванні нових ринкових ланцюгів вартості на засадах паритетних взаємодій їх учасників та активної участі держави у формуванні відтворювальної логістики товарних ринків. 
Аналіз останніх досліджень і публікацій. Дослідженню тенденцій і проблем розвитку внутрішнього ринку ПЯП присвячено праці Л.А. Костюк, К.В. Мазур, А.М. Кандиби, Т.А. Маркіної, О.В.Рибакової, І.В. Сало, О.М. Шестопаля та інших науковців. Питання розвитку теорії і методології логістики товарних ринків посідають чільне місце у працях Б.В.Буркинського ${ }^{1}$, В.М.Лисюка, М.Л. Тараканова ${ }^{2}$ та ін. Проте малодослідженими залишаються питання діагностики сучасних тенденцій розвитку ринку ПЯП улогістичному вимірі, трансформації структури ринкового логістичного ланцюга для підвищення його ефективності, регулювання логістичного розвитку даного ринку на основі відтворювального підходу, обумовлюючи необхідність нових розробок у даному науковому напрямі.

Постановка задачі. Метою статті є оцінка логістичних тенденцій українського ринку ПЯП, визначення базового логістичного «розриву» потокових процесів, обгрунтування структури ефективного логістичного ланцюга кооперативного типу на засадах паритетних взаємодій його учасників, а також стратегічних напрямів і заходів державного стимулювання розбудови ефективної логістики ринку на основі відтворювального підходу. У процесі дослідження використано методи діалектики, синтезу, структурно-динамічний і порівняльний аналіз, монографічний метод.

Виклад основного матеріалу. В Україні обсяги виробництва ПЯП в 2018 р. досягли 2,57 млн. т, збільшившись порівняно з 2011 р. на 35,6 \% за рахунок зростання урожайності культур (на 51,2 \%), що стало можливим завдяки впровадженню інноваційних технологій (табл. 1). При цьому площі плодово-ягідних насаджень перманентно скорочуються (на 10,6 \%) внаслідок вибуття старих садів та недостатності інвестицій на закладку нових садів. Особливістю аграрної ланки ринкового ланцюга $€$ домінування індивідуального сектору, що об'єднує фермерські й особисті селянські господарства, у виробництві ПЯП: у звітному році на його частку припало 83,6 \% державного виробництва ПЯП, решту ніші (16,4 \%) зайняли агропідприємства корпоративного сектору.

Таблиця 1

Базові показники розвитку плодово-ягідного ринку України, тис. т

\begin{tabular}{|c|c|c|c|c|c|c|c|c|}
\hline \multirow{2}{*}{ Показники } & \multicolumn{7}{|c|}{ Роки } & \multirow{2}{*}{$\begin{array}{c}2018 \text { p. } \\
\text { y \% } \\
\text { до } 2011 \text { p. }\end{array}$} \\
\hline & 2011 & 2013 & 2014 & 2015 & 2016 & 2017 & 2018 & \\
\hline $\begin{array}{l}\text { 1. Площа насаджень, тис. } \\
\text { га }\end{array}$ & 255,0 & 253,0 & 239,0 & 235,0 & 224,0 & 226,0 & 228,0 & 89,4 \\
\hline 2. Виробництво ПЯП & 1896 & 2295 & 1999 & 2153 & 2007 & 2048 & 2571 & 135,6 \\
\hline $\begin{array}{l}\text { у т.ч. індивідуальний } \\
\text { сектор }\end{array}$ & 1635 & 1895 & 1723 & 1809 & 1732 & 1790 & 2150 & 131,5 \\
\hline у\% до виробниитва & 86,2 & 82,6 & 86,2 & 84,0 & 86,3 & 87,4 & 83,6 & $\mathrm{X}$ \\
\hline 3. Урожайність, ц/га & 84,9 & 103,5 & 95,2 & 104,5 & 101,9 & 103,1 & 128,4 & 151,2 \\
\hline 4. Імпорт ПЯП & 901,9 & 913,9 & 703,3 & 498,3 & 609,2 & 658,5 & 709,7 & 78,7 \\
\hline у\% до виробництва & 47,6 & 39,8 & 35,2 & 23,1 & 30,4 & 32,2 & 27,6 & $\mathrm{X}$ \\
\hline 5.Експорт ПЯП, тис. т & 105,7 & 69,6 & 69,8 & 66,2 & 83,6 & 90,6 & 112,6 & 106,5 \\
\hline у\% до виробництвва & 5,6 & 3,0 & 3,5 & 3,1 & 4,2 & 4,4 & 4,4 & $\mathrm{X}$ \\
\hline 6. Смність ринку ПЯП & 2692 & 3140 & 2633 & 2585 & 2533 & 2616 & 3168 & 117,7 \\
\hline $\begin{array}{l}\text { 7. Ступінь відкритості } \\
\text { ринку, \% (4/6) }\end{array}$ & 33,5 & 29,1 & 26,7 & 19,3 & 24,1 & 25,2 & 22,4 & $\mathrm{X}$ \\
\hline
\end{tabular}

*Розраховано авторами за даними Державної служби статистики України ${ }^{3}, 4$

\footnotetext{
${ }^{1}$ Буркинський, Б. В., Нікішина, О. В., Лисюк, В. М. та інші (2020) Методологічні засади формування ефективної логістики товарних ринків:Одеса: ІПРЕЕД НАН України.

${ }^{2}$ Нікішина, О. В., Діленко, В. О., Тараканов, М. Л. (2019). Логістичний фактор трансформації теоретичних положень функціонування товарних ринків. Проблеми економіки, 3 (41), 164-170.

DOI: https://doi.org/10.32983/2222-0712-2019-3-164-170.

3 Державна служба статистики України (2019). Баланси та споживання основних продуктів харчування населенням України: статистичний збірник. Київ, 59.

${ }^{4}$ Офіційний сайт Державної служби статистики України (2020). Головна сторінка $<\mathrm{http}: / /$ www.ukrstat.gov.ua/> (2020, червень, 01).
} 
Незважаючи на тенденцію скорочення імпорту ПЯП (на 21,3 \%), його обсяги залишаються досить значними - 709,7 тис. т або 27,6 \% від обсягів виробництва, обумовлюючи істотний ступінь відкритості ринку для міжнародної торгівлі - 22,4 \% в 2018 р. (див. табл. 1). Експорт ПЯП у 6 разів менший його імпорту і складає 112,6 тис. т або 4,4 \% від обсягів виробництва. Частка імпорту у внутрішньому споживанні складає $22,4 \%$, що свідчить про високу потужність руху імпортних товаропотоків у ринковому ланцюгу ПЯП.

Проведені дослідження дозволили встановити такі головні логістичні тенденції розвитку плодово-ягідного ринку України:

1. домінування в аграрній ланці дрібнотоварного виробництва;

2. наявність посередницьких ланок у структурі ринкового ланцюга;

3. недостатність фруктосховищ для зберігання ПЯП у регіонах;

4. обмежений доступ первинних індивідуальних виробників до прибуткової ланки розподілу й реалізації ПЯП;

5. необ'єктивний перерозподіл доданої вартості між ланками ланцюга;

6. критичний рівень імпортної ПЯП у вітчизняній торговельній мережі;

7. висока потужність руху імпортних товаропотоків у ланцюгу, втрати суб'єктів, споживачів і держави від неефективної логістики ринку ПЯП.

Про масштаби розвитку посередницьких ланок у логістичному ланцюгу ринку ПЯП певне уявлення надає аналіз структури реалізації продукції за основними збутовими каналами (табл. 2). У 1990 р. за переробним каналом було реалізовано виробниками 86,8 \% ПЯП, у 1995 р. - 40,4 \%, у 2005 p. і 2015 pp. - 13,4 \% і 24,3 \% відповідно. За аналізований період частка посередницького «іншого» збутового каналу зросла з 4,4 \% в 1995 р. до 64,7 \% в 2015 р. За 2016-2018 рр. статистичне спостереження за формою табл. 2 не велося, однак, врахувавши стійку тенденцію до зростання непрозорого «іншого» каналу, можна спрогнозувати приріст його частки до $70 \%$ за рахунок зменшення питомої ваги переробного збутового каналу. Відтак, за 1990-2018 рр. відбулися структурні зміни у ринковому ланцюгу ПЯП в напрямі переорієнтації руху внутрішніх товаропотоків із переробної до посередницької ланок, що супроводжувалося втратою доданої вартості як аграрних виробників, так і переробних підприємств. При цьому обсяги внутрішньої переробки ПЯП в Україні скорочуються. Так, у 2018 р. порівняно з 2013 р. обсяги виробництва яблучного соку зменшилися на 39,4 \% і склали 106 млн. л, суміші соків фруктових і овочевих - на 32,4 \% (184 л. у 2018 р.), соків неконцентрованих з одного виду фруктів або овочів - на 51,4 \% $\left(75,8\right.$ л) ${ }^{1}$.

Таблиця 2

Структура реалізації плодово-ягідної продукції агропідприємствами України *

\begin{tabular}{|l|c|c|c|c|c|c|c|c|}
\hline \multirow{2}{*}{ Канали реалізації агропродукції } & \multicolumn{7}{|c|}{ Роки } & $\begin{array}{c}\text { Зміни } \\
(+,-)\end{array}$ \\
\cline { 2 - 10 } & 1990 & 1995 & 2000 & 2005 & 2010 & 2013 & 2015 & \\
\hline 1. Переробним підприємствам & 86,8 & 40,4 & 16,1 & 13,4 & 25,0 & 23,8 & 24,3 & $-62,5$ \\
\hline 2. На ринку & 9,8 & 40,6 & 49,8 & 33,0 & 25,1 & 13,5 & 10,8 & 1 \\
\hline 3. Населенню & 3,4 & 14,6 & 22,7 & 6,0 & 0,8 & 0,2 & 0,2 & $-3,2$ \\
\hline 4. За іншими каналами & 0,0 & 4,4 & 11,4 & 47,6 & 49,1 & 62,5 & $\mathbf{6 4 , 7}$ & 57,7 \\
\hline
\end{tabular}

*Розраховано авторами за даними Державної служби статистики Украӥни ${ }^{2}$.

Натомість у роздрібній торговельній мережі перманентно зростає частка імпортної ПЯП (включаючи виноград) - 333,4 \% в 2005 р. до 63,5 \% в 2018 р., що значно вище середнього показника по групі продовольчих товарів (табл. 3). За аналізований період частка імпортних фруктово-ягідних консервів зросла з 17,1 до 46,9\%, овочевих - 3 19,2 \% до 26,2 \% відповідно. Слід зазначити, що показник частки продажу імпортних продовольчих товарів через роздрібну торговельну мережу $є$ одним із індикаторів продовольчої безпеки відповідно до чинних методичних рекомендацій;

\footnotetext{
${ }^{1}$ Державна служба статистики України (2019). Статистичний щзорічник України за 2018 рік. Київ:, 261.

2 Державна служба статистики України (2016). Статистичний щзорічник України за 2015 рік. Київ:, 306.
} 
його оптимальним рівнем $є 12 \%$, небезпечним - $23 \%$, критичним $-25 \%{ }^{1}$. Даний індикатор запропоновано використати для оцінки потужності руху зовнішніх товаропотоків, як складової діагностики ефективності ринкових ланцюгів ${ }^{2}$. За нормативним коридором значень ПЯП і продукти iii переробки мають критичний рівень (понад $25 \%$ ), сигналізуючи про погрози національній продовольчій безпеці та необхідність впровадження виваженої політики імпортозаміщення товарів, для випуску яких Україна має значний нереалізований природно-ресурсний потенціал.

Таблиця 3 Частка продажу імпортних продовольчих товарів через роздрібну торговельну мережу
вітчизняних підприємств в Україні, \%"

\begin{tabular}{|l|c|c|c|c|c|c|c|c|c|}
\hline \multirow{2}{*}{\multicolumn{1}{|c|}{ Показники }} & \multicolumn{7}{|c|}{ Роки } & \multirow{2}{*}{$\begin{array}{c}\text { Рівень } \\
\text { ПБ** }\end{array}$} \\
\cline { 1 - 10 } & 2005 & 2010 & 2013 & 2014 & 2015 & 2016 & 2017 & 2018 & Задов. \\
\hline 1. Продовольчі товари & $\mathbf{9 , 1}$ & $\mathbf{1 1 , 8}$ & $\mathbf{1 4 , 5}$ & $\mathbf{1 4 , 4}$ & $\mathbf{1 4 , 8}$ & $\mathbf{1 5 , 2}$ & $\mathbf{1 7 , 8}$ & $\mathbf{1 8 , 6}$ & Крит. \\
\hline $\begin{array}{l}\text { 2. Свіжі плоди, ягоди, } \\
\text { виноград, горіхи }\end{array}$ & 33,4 & 39,2 & 47,5 & 52,9 & 55,0 & 59,0 & 62,3 & $\mathbf{6 3 , 5}$ & Крит. \\
\hline 3.Свіжі овочі & 9,5 & 9,4 & 17,0 & 15,5 & 16,1 & 16,7 & 15,8 & 14,6 & Задов. \\
\hline $\begin{array}{l}\text { 4.Овочі та фрукти } \\
\text { перероблені }\end{array}$ & 0 & 0 & 0 & 34,2 & 34,9 & 36,1 & 36,4 & 38,3 & Крит. \\
\hline 5. Консерви фруктово-ягідні & 17,1 & 35,3 & 44,4 & 42,3 & 38,6 & 39 & 44,7 & $\mathbf{4 6 , 9}$ & Крит. \\
\hline 6. Консерви овочеві & 19,2 & 18,6 & 22,5 & 24,3 & 24,4 & 24,5 & 24,9 & 26,2 & Крит. \\
\hline
\end{tabular}

"Розраховано авторами за даними Державної служби статистики Украӥни

*** ПБ-продовольча безпека; Задов. - задовільний рівень; Крит. - критичний рівень.

Проведені дослідження засвідчили логістичний «розрив» потокових процесів між індивідуальним сектором аграрної ланки i наступними ланками ринкового ланцюга, його неефективність та неспроможність реалізувати головний цільовий орієнтир - забезпечення розширеного відтворення товароруху та оптимізацію загальної ринкової доданої вартості. Подолання даного базового логістичного «розриву» має принципове значення для відтворювального розвитку всього вітчизняного ринку ПЯП, обумовлюючи необхідність впровадження регуляторних заходів держави для подолання логістичної відторгненості дрібних виробників та їх входження (інтеграції) до прибуткової ланки розподілу й реалізації продукції. На наш погляд, регулювання логістичного розвитку ринку ПЯП доцільно здійснювати за двома стратегічними напрямами: (1) стимулювання створення мережі плодово-ягідних кооперативів, зокрема багатофункціональних; (2) підтримка розбудови оптових ринків сільськогосподарської продукції (далі - ОРСП) у регіонах.

Станом на 01 липня 2019 р. в економіці України функціонувало 27,796 тис. кооперативних об'єднань, з них 3,6 \% займали виробничі і 4,5 \% сільськогосподарські обслуговуючі кооперативи (СОК). Усвідомлення індивідуальними господарствами потенційних можливостей обслуговуючої кооперації активізувало її процеси в Україні. Так, порівняно з 01 січня 2018 р. кількість діючих СОК зросла на 20,5 \% і склала в 2019 р. 735 одиниць (таблиця 4). За минулий рік найбільший приріст був притаманний плодоовочевим кооперативам (на 43 \%), найменший - зерновим (2,5%).

Важливим інструментом регулювання розвитку СОК в Україні $є$ відшкодування кооперативам 70 \% вартості придбаного обладнання для зберігання та переробки агропродукції. В результаті впровадження даного регуляторного заходу три плодово-ягідних кооперативи придбали в 2019 р. 16 одиниць обладнання для створення цехів первинної переробки та зберігання ПЯП (охолодження

\footnotetext{
${ }^{1}$ Наказ про методичні рекомендації щзодо розрахунку рівня економічної безпеки Украӥни, 2013

(Міністерство економічного розвитку і торгівлі України). Офіиіийний сайт Верховної Ради Украӥни $<$ https://zakon.rada.gov.ua/rada/show/v1277731-13\#n9> (2020, червень, 01).

2 Буркинський, Б. В., Нікішина, О. В. (2020). Діагностика ефективності логістичних ланцюгів товарних ринків. Одеса: ІПРЕЕД НАН України, 75.

${ }^{3}$ Офіційний сайт Державної служби статистики України (2020). Головна сторінка <http://www.ukrstat.gov.ua/> (2020, червень, 01).
} 


\section{Динаміка та видова структура діючих сільськогосподарських обслуговуючих кооперативів в Україні*}

\begin{tabular}{|l|c|c|c|c|c|c|}
\hline \multirow{2}{*}{ Види СОК } & \multicolumn{2}{|c|}{2018 рік } & \multicolumn{2}{c|}{2019 рік } & \multicolumn{2}{c|}{ Зміни (+,-) } \\
\cline { 2 - 7 } & Одиниць & $\%$ & Одиниць & $\%$ & Одиниць & \% \\
\hline Усього, у тому складі: & $\mathbf{6 1 0}$ & $\mathbf{1 0 0 , 0}$ & $\mathbf{7 3 5}$ & $\mathbf{1 0 0 , 0}$ & $+\mathbf{1 2 5}$ & $+\mathbf{2 0 , 5}$ \\
\hline 1. Молочарські & 142 & 23,3 & 186 & 25,3 & +44 & $+31,0$ \\
\hline $\begin{array}{l}\text { 2. 3 обробітку землі та збирання } \\
\text { врожаю }\end{array}$ & 146 & 23,9 & 162 & 22,0 & +16 & $+11,0$ \\
\hline 3.М'ясні & 51 & 8,4 & 35 & 4,8 & -16 & $-31,4$ \\
\hline 4.Плодоовочеві & 79 & 13,0 & 113 & 15,4 & +34 & $+43,0$ \\
\hline 5. Зернові & 40 & 6,6 & 41 & 5,6 & +1 & $+2,5$ \\
\hline 6. 3 надання інших послуг & 152 & 24,9 & 198 & 26,9 & +46 & $+30,3$ \\
\hline
\end{tabular}

*Розраховано авторами за даними Кабінету Міністрів Украӥни 1 .

та глибока заморозка) $)^{2}$. Відтак, головний вектор регуляторного впливу держави спрямовано на цільову підтримку багатофункціональних кооперативів, які поєднують декілька видів діяльності та орієнтовані на переробку сировини, формуючи таким чином ефективний кооперативний логістичний ланцюг. У ньому за рахунок нівелювання посередницьких ланок та паритетних взаємодій між суб'єктами досягається більш справедливий розподіл доданої вартості та оптимізація ціни товару (рис. 1). Слід зазначити, що в Україні на частку багатофункціональних і переробних припадає 23,8\% і 15,9 \% діючих СОК відповідно ${ }^{3}$.

Існуючий ланцюг ринку ПЯП України $є$ неефективним 3 причини наявності декількох посередницьких ланок та логістичного відторгнення первинних виробників від ланок зберігання й збуту продукції. Натомість кооперативний ланцюг, що пропонується, передбачає більш справедливий розподіл доданої вартості між його учасниками на паритетних засадах. Ефективне функціонування кооперативного ланцюга досягається за рахунок налагодження паритетних зв'язків взаємодії між учасниками як всередині ринкового ланцюга, так і ззовні, тобто між ним і різними стейкхолдерами, зацікавленими в розбудові кооперативних ланцюгів аграрного ринку, зокрема, переробними підприємствами, територіальними громадами, державними й профільними інституціями та ін. Зв'язки взаємодії (внутрішні та зовнішні) виступають формою впровадження економічних інтересів учасників ринкових логістичних ланцюгів ${ }^{4}$.

Становлення конкурентоспроможних кооперативних ланцюгів ринку ПЯП дозволить їх суб'єктам ефективно взаємодіяти із існуючими ланцюгами корпоративного або посередницького типу на основі економічного партнерства. Частину виробленої ПЯП багатофункціональні кооперативи можуть передавати на зберігання, доробку, переробку або реалізацію суб'єктам існуючих логістичних ланцюгів на паритетних засадах, зберігаючи при цьому достатній рівень відтворювальної спроможності (див. рис. 1). Іншу частину продукції кооперативи можуть реалізувати через мережу ОРСП та їх магазини фірмової торгівлі. На нашу думку, інтеграція ОРСП у структуру кооперативного ланцюга ринку ПЯП значно підсилить його конкурентоспроможність та дозволить поетапно розбудувати прямий (без посередників) канал збуту продукції, скоротити імпортозалежність ринку та наростити експортні товаропотоки продукції з високою доданою вартістю. Структура ОРСП наведена на рис. 2.

\footnotetext{
${ }^{1}$ Шеремета, В. (2020) В Україні зростає кількість обслуговуючих кооперативів. Урядовий портал.

$<$ https://www.kmu.gov.ua/ua/news/v-ukrayini-zrostaye-kilkist-obslugovuyuchih-kooperativiv-viktor-sheremeta $>$ (2020, червень, 01).

2 Там само.

${ }^{3}$ Саковська, О. М. (2019). Роль сільськогосподарських кооперативів у розвитку аграрного сектора економіки: порівняльний аспект. Агросвіт, 21, 66-73.

${ }^{4}$ Буркинський, Б. В., Нікішина, О. В. (2020) Теоретико-методичний підхід до взаємодії економічних інтересів суб'єктів логістичних ланџңюгів товарних ринків. Одеса: ІПРЕЕД НАН України, 63.
} 


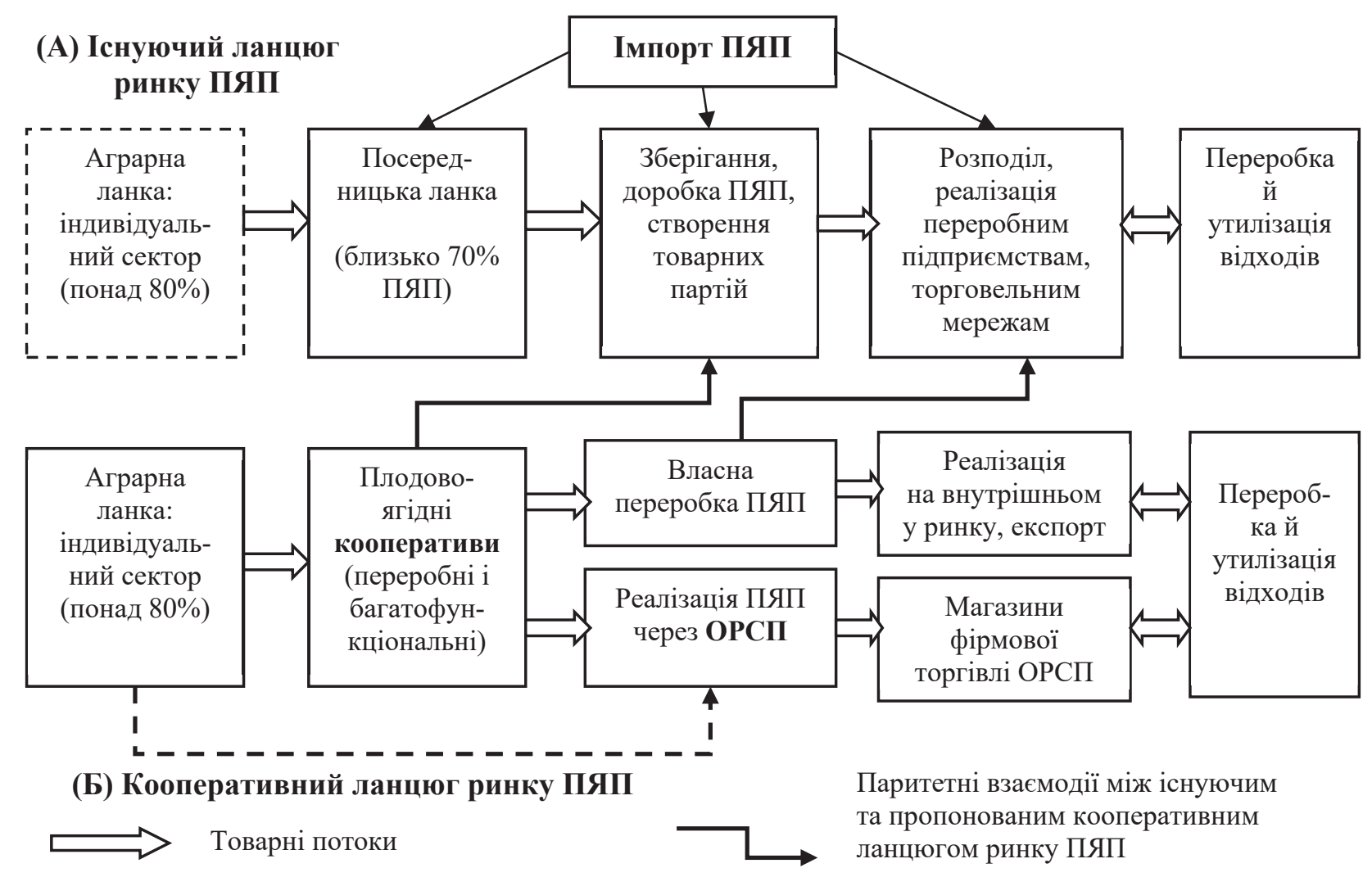

\section{Рис. 1. Структура існуючого та кооперативного логістичних ланцюгів ринку ПЯП в Україні [авторська розробка]}

Структурну будову ОРСП формують три взаємопов'язані складові, кожна з яких поєднує низку внутрішніх компонентів: (1) технічно-управлінська; (2) виробнича; (3) інфраструктурна.

Технічно-управлінська складова включає структурні технічні підрозділи ОРСП, магазини фірмової роздрібної торгівлі і логістично-маркетинговий центр (див. рис. 2). На відміну від існуючих моделей ОРСП, ми пропонуємо створення на базі таких ринків мереж магазинів фірмової роздрібної торгівлі, максимально наближених до кінцевих споживачів, з метою їх стабільного забезпечення якісною вітчизняною ПЯП протягом року за цінами, нижчими цін великих продовольчих мереж. Такий захід дозволить сформувати прямі економічні зв'язки між індивідуальними виробниками та їх кооперативами з кінцевими споживачами, що сприятиме більш справедливому розподілу доданої вартості у логістичному ланцюгу ринку ПЯП.

Логістично-маркетинговий центр виконує уструктурі ОРСП важливі функції щодо інтегрованого управління формуванням ефективного логістичного ланцюга на засадах узгодження економічних інтересів його учасників, передусім дрібних товаровиробників та оптових покупців. Це дозволяє знівелювати зайві посередницькі ланки ринкового ланцюга, оптимізувати його структурну будову, забезпечити справедливу ринкову ціну продукції, зменшити цінову волатильність на ринку. Окрім управлінської, центр виконує функцію дослідження потенційних ринків збуту, у т.ч. зовнішніх, оцінює ринкову кон'юнктуру, трансформаційний вплив світових тенденцій на відтворювальний розвиток внутрішніх агропродовольчих ринків. Також центр надає інформацію виробникам i покупцям продукції щодо рівнів цін, обсягів попиту та пропозиції на ринку, їх співвідношення тощо. Логістично-маркетинговий центр формує на паритетних засадах стійкі зв'язки взаємодій виробників із переробними підприємствами і оптовими покупцями.

Виробнича складова у структурі ОРСП виконує важливі функції збільшення доданої вартості продукції у процесі іiї зберігання та доробки, забезпечення якості ПЯП, нарощування потужностей сучасних фруктосховищ в Україні, сталого розвитку ринкової логістики шляхом утилізації й переробки відходів (див. рис. 2). Відділ матеріально-технічного забезпечення здійснює постачання матеріальних ресурсів для організації діяльності структурних підрозділів ОРСП. Виставковий центр 


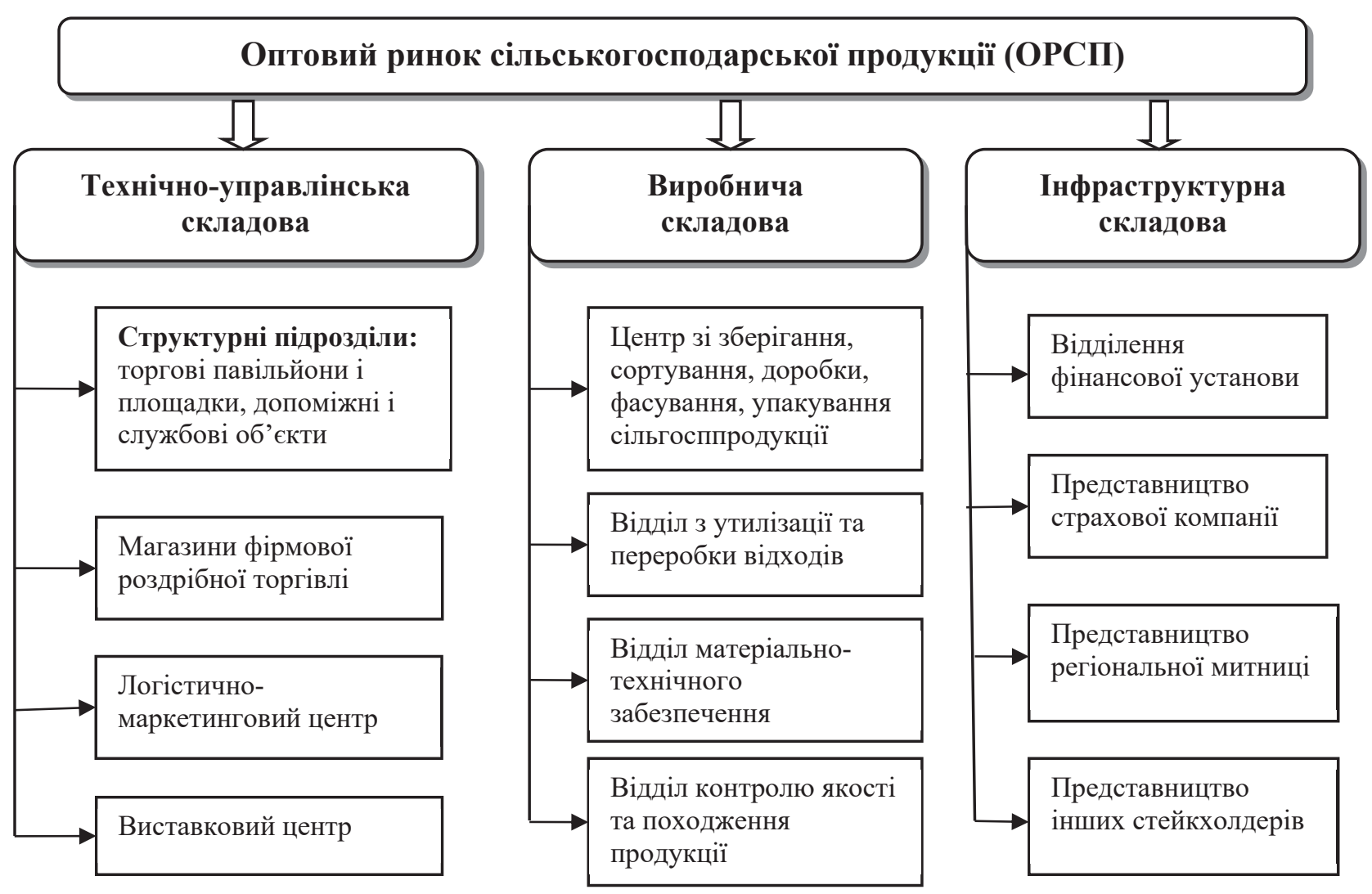

Рис. 2. Структурна будова оптового ринку сільськогосподарської продукції [авторська розробка]

виконує інформаційно-рекламну функцію для залучення потенційних стейкхолдерів до співробітництва з ОРСП. У структурі виробної складової ринку також передбачено відділ контролю якості та походження продукції.

Інфраструктурна компонента здійснює фінансове, страхове забезпечення роботи ОРСП. До їі складу також входить представництво регіональної митниці, яка виконує функції митного контролю та оформлення зовнішньоторговельних операцій. Представництво інших стейкхолдерів включає державні та профільні інституції, зацікавлені у розвитку ринкової інфраструктури регіону, а також сільські громади, члени яких, як виробники аграрної продукції, отримують можливість доступу до прибуткової ланки розподілу та реалізації товарів через ОРСП. Це сприяє розвитку сільської інфраструктури, підвищенню доходів і зайнятості членів громад, становленню європейської моделі поліфункціонального розвитку сільських територій.

Практика свідчить, що ОРСП створюються переважно в акціонерній формі власності, важливим інститутом якої є державно-приватне партнерство. Воно передбачає участь держави в акціонерному капіталі ОРСП, створення сприятливих умов для залучення інвестицій, надання земельних ділянок та дозвільних документів для будівництва ОРСП, забезпечення пріоритетної участі малих і середніх товаровиробників у статутному фонді ОРСП.

Слід підкреслити важливу роль ОРСП у скороченні імпортних товаропотоків на ринку ПЯП шляхом формування та розвитку мережі фірмових магазинів роздрібної торгівлі, як альтернативи великим торговельним мережам (див. рис. 2). На нашу думку, інтеграція ОРСП у структуру логістичних ланцюгів ринків ПЯП $є$ важливим заходом на шляху реалізації виваженої політики імпортозаміщення товарів. За традиційним підходом політика імпортозаміщення передбачає заходи, спрямовані на зростання виробництва вітчизняних товарів поряд зобмеженням імпорту або оптимізацією його структури ${ }^{1}$. На українському ринку ПЯП доцільно застосувати логістичний підхід

\footnotetext{
${ }^{1}$ Валевич, Р. П., Свиренко, Н. Е. (2019). Политика импортозамещения: новые подходы к формированию и реализации. Научные труды Белорусского государственного экономического университета, 1, $72-79$.
} 
до політики імпортозаміщення у вигляді системи заходів, орієнтованих на просування вітчизняної продукції індивідуальних виробників до кінцевого споживача на фоні оптимізації імпорту ПЯП.

Проведений аналіз товарної структури імпорту ПЯП в Україну засвідчив домінування цитрусових та бананів - 43,7 \% і 29,1\% в 2018 р. відповідно (табл. 5). Водночас від'ємне сальдо мають такі товарні групи, як абрикоси, вишні, черешні (УКТЗЕД 809), плоди сушені (813), варення й джеми (2007), плоди й горіхи, приготовлені іншим способом (2008), плодово-овочеві соки (2009), для виробництва яких Україна має достатній природно-ресурсний потенціал. Імпорт саме цих товарів може бути заміщений вітчизняною ПЯП та продуктами іiі переробки, виготовлених, зокрема, i багатофункціональними кооперативами. Найбільшим попитом на зовнішньому ринку користуються українські горіхи (51,3\% експорту ПЯП в 2018 р.) та плодово-овочеві соки $(75,8$ \% продуктів переробки овочів і фруктів). Головними країнами-імпортерами українських соків в 2018 р. були Австрія (22 \%), Польща (20 \%) та Німеччина (18,5\%), горіхів - Туреччина $(17,4 \%)$, Греція (11 \%) та Франція (9,4%). Загалом у 2018 р. від’ємне сальдо зовнішньої торгівлі ПЯП склало 267,1 млрд. дол., продуктами їі переробки - 8,98 млрд. дол.

Таблиця 5

Товарна структура та сальдо зовнішньої торгівлі України плодами та продуктами їх переробки в 2018 р."

\begin{tabular}{|c|c|c|c|c|c|c|}
\hline \multirow{2}{*}{ Код УКТЗЕД } & \multirow{2}{*}{ Товарні позиції } & \multicolumn{2}{|c|}{ Експорт } & \multicolumn{2}{|c|}{ Імпорт } & \multirow{2}{*}{$\begin{array}{l}\text { Сальдо, } \\
\text { тис. дол. }\end{array}$} \\
\hline & & Тис. дол. & $\%$ & Тис. дол. & $\%$ & \\
\hline 8 & $\begin{array}{l}\text { Ïстівні плоди та горіхи, всього, } \\
\text { у т.ч. }\end{array}$ & 228434 & 100 & 495552 & 100 & -267118 \\
\hline 801000000 & $\begin{array}{l}\text { Горіхи кокосові, бразильські, } \\
\text { кеш’ю }\end{array}$ & 33 & 0,01 & 9662 & 1,9 & -9629 \\
\hline 802000000 & Інші горіхи, свіжі або сушені & 117139 & 51,3 & 18047 & 3,6 & 99092 \\
\hline 803000000 & Банани свіжі або сушені & 27 & 0,01 & 144287 & 29,1 & -144260 \\
\hline 804000000 & $\begin{array}{l}\text { Фініки, інжир, ананаси, } \\
\text { авокадо,манго свіжі або сушені }\end{array}$ & 6 & 0,003 & 25624 & 5,2 & -25618 \\
\hline 805000000 & Цитрусові свіжі або сушені & 448 & 0,2 & 216527 & 43,7 & -216078 \\
\hline 807000000 & Дині, кавуни свіжі & 3323 & 1,5 & 1079 & 0,2 & 2244 \\
\hline 808000000 & Яблука, груші та айва свіжі & 15174 & 6,6 & 3540 & 0,7 & 11634 \\
\hline 809000000 & $\begin{array}{l}\text { Абрикоси, вишні, черешні, } \\
\text { персики, сливи та терен свіжі }\end{array}$ & 3166 & 1,4 & 21722 & 4,4 & -18556 \\
\hline 810000000 & Інші плоди свіжі & 8214 & 3,6 & 41651 & 8,4 & -33437 \\
\hline 811000000 & $\begin{array}{l}\text { Плоди та горіхи, сирі або варені, } \\
\text { морожені, з цукром і без цукру }\end{array}$ & 78237 & 34,2 & 4234 & 0,9 & 74003 \\
\hline 813000000 & Плоди сушені & 2667 & 1,2 & 9180 & 1,9 & -6513 \\
\hline 20 & $\begin{array}{l}\text { Продукти переробки овочів і } \\
\text { фруктів, всього, у т.ч. }\end{array}$ & 101823 & 100,0 & 110805 & 100,0 & -8982 \\
\hline 200600000 & $\begin{array}{l}\text { Овочі, плоди, горіхи } \\
\text { консервовані з додаванням цукру }\end{array}$ & 3043 & 3,0 & 845 & 0,8 & 2198 \\
\hline 200700000 & Варення, джеми, плодові желе & 2846 & 2,8 & 9268 & 8,4 & -6423 \\
\hline 200800000 & $\begin{array}{l}\text { Плоди, горіхи, приготовлені або } \\
\text { консервовані іншим способом }\end{array}$ & 18774 & 18,4 & 49015 & 44,2 & -30241 \\
\hline 200900000 & Соки 3 плодів або овочів & 77160 & 75,8 & 38281 & 34,5 & 38880 \\
\hline
\end{tabular}

* Розраховано авторами за даними Держсавної служби статистики України ${ }^{1}$

\footnotetext{
${ }^{1}$ Офіційний сайт Державної служби статистики України (2020). Головна сторінка

$<$ http://www.ukrstat.gov.ua/>(2020, червень, 01).
} 
Важливою складовою імпортозаміщення на ринку ПЯП повинні стати маркетингові стратегії просування продукції для переорієнтації споживчого попиту з імпортних на вітчизняні товари. В реалізації цього завдання велика роль належить логістично-маркетинговим центрам та мережам фірмової торгівлі ОРСП (див. рис. 2). Досвід Білорусі щодо впровадження проектів імпортозаміщення продовольства засвідчив їх невисоку результативність; незважаючи на зростання виробництва овочів i фруктів, попит населення не переключився на вітчизняну продукцію ${ }^{1}$. Закономірності зворотної реакції продовольчих ринків на політику імпортозаміщення іноземних країн доцільно враховувати в ході впровадження державної стратегії імпортозаміщення та обгрунтовувати найбільш оптимальні форми взаємодії у ринковому вимірі.

Висновки. У ході дослідження встановлено, що базовим логістичним «розривом» потокових процесів ринку ПЯП є обмежений доступ індивідуальних господарств, що виробляють 84 \% плодів і ягід в Україні, до прибуткових ланок зберігання, розробки й реалізації продукції, контрольованих посередниками й великими торговельними мережами. Наслідком існуючої логістичної відторгненості первинних виробників $\epsilon$ порушення їх прямих економічних зв'язків із оптовими покупцями, необ'єктивний перерозподіл доданої вартості між ланками ринкового ланцюга, надмірна кількість посередницьких ланок, через які реалізується близько 70 \% ПЯП, критичний рівень імпортних плодів і ягід у вітчизняній торговельній мережі, низка структурних і цінових дисбалансів, що є свідченням неефективної логістики плодово-ягідного ринку України.

Обгрунтовано необхідність регулювання логістичного розвитку ринку ПЯП за двома стратегічними напрямами: стимулювання створення й розвитку багатофункціональних кооперативів та державна підтримка розбудови мережі ОРСП у регіонах України. Розроблено структуру кооперативного логістичного ланцюга ринку ПЯП, ефективне функціонування якого передбачає налагодження паритетних зв'язків взаємодії як між ланками всередині ланцюга, так і ринковими ланцюгами різних типів на основі рівноправного колективного партнерства. На думку авторів, інтеграція в структуру кооперативного ланцюга логістичного центру (ОРСП) та мережі його фірмових магазинів значно підсилить його конкурентоспроможність, дозволить зменшити імпортозалежність ринку та наростити експорт продуктів переробки плодів і ягід. Обгрунтовано структурну будову ОРСП, яка на відміну від існуючих моделей, включила магазини фірмової роздрібної торгівлі, представництва різних стейкхолдерів та логістично-маркетинговий центр. Наголошено на важливій ролі такого центру в реалізації політики імпортозаміщення на ринку ПЯП.

Головними інструментами державного регулювання логістичного розвитку плодово-ягідного ринку України мають бути компенсація вартості обладнання для переробних і багатофункціональних кооперативів, пільгові кредити для будівництва фруктосховищ, підтримка створення ОРСП на засадах державно-приватного партнерства, виділення земельних ділянок для їх будівництва, інформаційне та інституційне забезпечення процесів кооперації й інфраструктурної розбудови ринку, державна підтримка виробників продуктів переробки плодів і ягід (у формі субсидій і податкових пільг) для реалізації стратегії імпортозаміщення й освоєння зовнішніх ринків збуту продукції, постійний моніторинг обсягів і цін імпортної ПяП уконтексті забезпечення національної продовольчої безпеки.

Наукова новизна проведеного дослідження полягає в обгрунтуванні науково-прикладних засад формування й регулювання ефективних логістичних ланцюгів ринку ПЯП на основі розбудови кооперативних ланцюгів із включенням багатофункціональних кооперативів, ОРСП та їх фірмових магазинів роздрібної торгівлі для об'єктивізації міжланкового перерозподілу доданої вартості, становлення паритетних зв'язків взаємодії між дрібними виробниками й оптовими покупцями, формування завершеного ланцюга товароруху продукції індивідуальних виробників, подолання структурних і цінових дисбалансів ринку, зменшення потужності руху імпортних товаропотоків та стимулювання експорту переробних товарів. Перспективи подальших досліджень полягають у розробці методичного забезпечення для оцінки ефективності функціонування логістичних ланцюгів товарних ринків, у т.ч. плодово-ягідного ринку України.

\footnotetext{
${ }^{1}$ Валевич, Р. П., Свиренко, Н. Е. (2019) Политика импортозамещения: новые подходы к формированию и реализации. Научные труды БГЭУ, 1, 72-79.
} 


\section{References:}

1. Burkynskyi, B. V., Nikishyna, O. V., Lysiuk, V. M. and others (2020). Metodolohichni zasady formuvannia efektyvnoi lohistyky tovarnykh rynkiv [Methodological bases of formation of effective logistics of commodity markets]. Odesa: IPREED NAN Ukrainy. [in Ukrainian].

2. Nikishyna, O. V., Dilenko, V. O., Tarakanov, M. L. (2019). Lohistychnyi faktor transformatsii teoretychnykh polozhen funktsionuvannia tovarnykh rynkiv [Logistic factor of transformation of theoretical provisions of functioning of commodity markets] Problemy ekonomiky [Problems of the economy], 3 (41), 164-170. DOI: https://doi.org/10.32983/2222-0712-2019-3-164-170. [in Ukrainian].

3. Derzhavna sluzhba statystyky Ukrainy (2019) [State Statistics Service of Ukraine (2019)]. Balansy ta spozhyvannia osnovnykh produktiv kharchuvannia naselenniam Ukrainy: statystychnyi zbirnyk [Balance and consumption of basic food products by the population of Ukraine: statistical collection]. Kyiv. [in Ukrainian].

4. Ofitsiinyi sait Derzhavnoi sluzhby statystyky Ukrainy [Official site of the State Statistics Service of Ukraine] (2020). Holovna storinka [Homepage] <http://www.ukrstat.gov.ua/> (2020, June, 01). [in Ukrainian].

5. Derzhavna sluzhba statystyky Ukrainy (2019) [State Statistics Service of Ukraine (2019)]. Statystychnyi shchorichnyk Ukrainy za 2018 rik [Statistical Yearbook of Ukraine for 2018]. Kyiv. [in Ukrainian].

6. Derzhavna sluzhba statystyky Ukrainy (2016) [State Statistics Service of Ukraine (2016)]. Statystychnyi shchorichnyk Ukrainy za 2015 rik [Statistical Yearbook of Ukraine for 2015]. Kyiv. [in Ukrainian].

7. Metodychni rekomendatsii shchodo rozrakhunku rivnia ekonomichnoi bezpeky Ukrainy, 2013 (Ministerstvo ekonomichnoho rozvytku i torhivli Ukrainy) [Methodical recommendations for calculating the level of economic security of Ukraine, 2013 (Ministry of Economic Development and Trade of Ukraine)]. Ofitsiynyy sayt Verkhovnoyi Rady Ukrayiny [Official site of the Verkhovna Rada of Ukraine] $<$ https://zakon.rada.gov.ua/rada/show/v1277731-13\#n9> (2020, June, 01). [in Ukrainian].

8. Burkynskyi, B. V., Nikishyna, O. V. (2020). Diahnostyka efektyvnosti lohistychnykh lantsiuhiv tovarnykh rynkiv [Diagnosis of the efficiency of logistics chains of commodity markets ]. Odesa: IPREED NAN Ukrainy [in Ukrainian].

9. Sheremeta, V. (2019). V Ukraini zrostaie kilkist obsluhovuiuchykh kooperatyviv. [In Ukraine, the number of service cooperatives is growing] Uriadovyi portal [Government portal]. $<\mathrm{https} / / /$ www.kmu.gov.ua/ua/news /v-ukrayini-zrostaye-kilkist-obslugovuyuchih-kooperativiv-viktor-sheremeta $>$ (2020, June, 01). [in Ukrainian].

10. Sakovska, O. M. (2019) Rol silskohospodarskykh kooperatyviv u rozvytku ahrarnoho sektora ekonomiky: porivnialnyi aspekt [The role of agricultural cooperatives in the development of the agricultural sector of the economy: a comparative aspect.] Ahrosvit [Agrosvit], 21, 66-73 [in Ukrainian].

11. Burkynskyi, B. V., Nikishyna, O. V. (2020). Teoretyko-metodychnyi pidkhid do vzaiemodii ekonomichnykh interesiv subiektiv lohistychnykh lantsiuhiv tovarnykh rynkiv [Theoretical and methodological approach to the interaction of economic interests of the subjects of logistics chains of commodity markets]. Odesa: IPREED NAN Ukrainy [in Ukrainian].

12. Valevich, R. P., Svirenko, N. E. (2019). Politika importozamescheniya: novyie podhodyi k formirovaniyu i realizatsii [Import substitution policy: new approaches to the formation and implementation]. Nauchnyie trudyi Belorusskogo gosudarstvennogo ekonomicheskogo universiteta [Scientific works of the Belarusian State Economic University], 1, 72-79. [in Russian]. 